RESEARCH ARTICLE

\title{
Glossidiella peruensis sp. nov., a new digenean (Plagiorchiida: Plagiorchiidae) from the lung of the brown ground snake Atractus major (Serpentes: Dipsadidae) from Peru
}

\author{
Eva Huancachoque $\mathbb{D}^{1}$, Gloria Sáez $\mathbb{D}^{1}$, Celso Luis Cruces $\left(\mathbb{D}{ }^{1,2}\right.$, Carlos Mendoza $\mathbb{D}^{3}$, \\ José Luis Luque $\mathbb{D}^{4}$, Jhon Darly Chero $\mathbb{D}^{1,5}$
}

\begin{abstract}
'Laboratorio de Parasitología General y Especializada, Facultad de Ciencias Naturales y Matemática, Universidad Nacional Federico Villarreal. 15007 El Agustino, Lima, Peru.

2 Programa de Pós-Graduação em Ciências Veterinárias, Universidade Federal Rural do Rio de Janeiro. Rodovia BR 465, km 7, 23890-000 Seropédica, RJ, Brazil.

${ }^{3}$ Escuela de Ingeniería Ambiental, Facultad de Ingeniería y Arquitecturas, Universidad Alas Peruanas. 22202 Tarapoto, San Martín, Peru.

${ }^{4}$ Departamento de Parasitologia Animal, Universidade Federal Rural do Rio de Janeiro. Caixa postal 74540, 23851-970 Seropédica, RJ, Brazil.

5 Programa de Pós-Graduação em Biologia Animal, Universidade Federal Rural do Rio de Janeiro. Rodovia BR 465, km 7, 23890-000 Seropédica, RJ, Brazil.

Corresponding author: Jhon Darly Chero (cristhian-5645@hotmail.com)
\end{abstract}

http://zoobank.org/30446954-FD17-41D3-848A-1038040E2194

\begin{abstract}
During a survey of helminth parasites of the brown ground snake, Atractus major Boulenger, 1894 (Serpentes: Dipsadidae) from Moyobamba, region of San Martin (northeastern Peru), a new species of Glossidiella Travassos, 1927 (Plagiorchiida: Plagiorchiidae) was found and is described herein based on morphological and ultrastructural data. The digeneans found in the lung were measured and drawings were made with a drawing tube. The ultrastructure was studied using scanning electron microscope. Glossidiella peruensis sp. nov. is easily distinguished from the type- and only species of the genus, Glossidiella ornata Travassos, 1927, by having an oblong cirrus sac (claviform in G. ornata), distinctly ovate testes (rounded testes in G. ornata) and button-like papillae on the dorsal edge of the oral sucker region (absent in G. ornata). In addition, $G$. peruensis sp. nov. differs from $G$. ornata by possessing a longer distance between testes and substantially wider oral and ventral suckers. This is the first time that a species of digenean is described and reported parasitizing snakes in Peru. KEY WORDS. Digenea, endoparasite, plagiorchiids, taxonomy, snake parasite.
\end{abstract}

\section{INTRODUCTION}

Atractus Wagler, 1828 (Serpentes: Dipsadidae) includes nearly 140 species of fossorial colubrids which are widely distributed throughout the Neotropical Region, occurring from Panama to Argentina (Myers 2003, Passos and Fernandes 2008, Arteaga et al. 2017). The brown ground snake, Atractus major Boulenger, 1894 is a mainly fossorial species, although occasionally it is cryptozoic and terrestrial and it, occurs in Colombia, Bolivia, Brazil, Ecuador, Peru and Venezuela (Nogueira et al. 2016). According to Martins and Oliveira (1999), this species of snake feeds mainly on earthworms, mites as well as small insects. Data on helminth parasites of $A$. major are scarce and restricted to a single record of the nematode Serpentirhabdias atracti Kuzmin, Melo \& Santos, 2014 (Rhabdiasidae) in Brazil (Kuzmin et al. 2014).

During a survey of helminth parasites of snakes from Moyobamba, region of San Martin (northeastern Peru), some digeneans were recovered from the lungs of $A$. major. Detailed morphological analysis based on light and scanning electron microscopy (SEM) revealed that the specimens represent a new species of Glossidiella Travassos, 1927 (Plagiorchiidae), which is described and illustrated herein. 


\section{MATERIAL AND METHODS}

One specimen of A. major was found dead in September 2016 , run over on the Highway Fernando Belaúnde Terry $\left(6^{\circ} 11^{\prime} \mathrm{S}\right.$; $\left.76^{\circ} 50^{\prime} \mathrm{W}\right)$ near the Mayo river, Moyobamba, San Martin region, Peru. The snake was collected by one of us (C. M.) and immediately dissected. The digestive tract and lungs were excised and placed in Petri dishes with saline solution $(0.90 \% \mathrm{NaCl})$ and examined for parasites with the use of a stereomicroscope. Nine specimens of a new digenean species belonging to the Plagiorchiidae were recovered alive from the lungs. Digenean specimens for staining purposes were killed with heat from an ethanol-burner flame, under slight coverslip pressure, and transferred to a vial of $70 \%$ alcohol. These specimens were stained in Semichon's acetic carmine. After dehydration using a graded ethanol series they were cleared with clove oil and mounted on glass slides using Canada balsam. Specimens were examined using a Leica-DM500 microscope with LEICA-ICC50 HD camera and Software LAS (Leica Application Suite), EZ versión 1.80, 2009, Switzerland and drawings were made with the aid of a drawing tube. Measurements are in micrometers, unless otherwise indicated, using straight-line distances between extreme points of the structures measured and are expressed as the range followed by the mean and number (n) of structures measured in parentheses. Two specimens were taken for scanning electron microscopy (SEM), dehydrated through a graded ethanol series, critical point dried with carbon dioxide, coated with gold and examined in an Inspect S50 - FEI, at an accelerating voltage of $7 \mathrm{kV}$. Specimens deposited in the Coleção Helmintológica do Instituto Oswaldo Cruz (CHIOC) of Glossidiella ornata Travassos, 1927 (holotype, CHIOC 5612; paratypes, CHIOC 5616-5617), were examined. Type material was deposited in the Helminthological and Minor Invertebrates Collection of the Museum of Natural History at the San Marcos University (MUSM), Peru.

\section{TAXONOMY}

Class Trematoda Rudolphi, 1808

Subclass Digenea Carus, 1863

Order Plagiorchiida La Rue, 1957

Plagiorchiidae Lühe, 1901

\section{Glossidiella peruensis sp. nov.}

http://zoobank.org/69E8EDC9-8672-464C-A389-DF93F0246D42 Figs $1-12$

Type host. Atractus major Boulenger, 1894 (Dipsadidae), brown ground snake.

Sites of infection. Lung.

Type locality. Highway Fernando Belaúnde Terry $\left(6^{\circ} 11^{\prime} S\right.$, $76^{\circ} 50^{\prime} \mathrm{W}$ ) near the Mayo river, Moyobamba, San Martin region, Peru. Intensity. 10 specimens found in a single snake examined. 4030a-f).
Description. Based on 7 whole mounted specimens and 2 SEM prepared specimens. Body elongate, slender, tapering posteriorly and markedly enlarged in anterior fifth of body, 12.78-14.56 (13.75; $\mathrm{n}=7) \mathrm{mm}$ long, $1.07-1.40(1.11 ; \mathrm{n}=8) \mathrm{mm}$ wide at level of ventral sucker. Length/width ratio 10.40-12.53 (11.40):1. Tegument spined (Figs 1, 5); spines almost imbricated, with central groove and curved distal tip (Figs 10-11), 16-19 (17; $\mathrm{n}=2$ ) long, directed posteriorly. Numerous small button-like papillae irregularly distributed on the dorsal edge of the oral sucker region (Figs 5). Forebody 11.56-16.22 (14.55; $\mathrm{n}=6) \mathrm{mm}$ long, occupying $9.1-12.6 \%(11.1 \% ; n=6)$ of body length. Oral sucker subterminal, muscular, 640-787 (719; $\mathrm{n}=7)$ long, 760-998 (829; $\mathrm{n}$ = 7) $\mathrm{mm}$ wide, $4.7-5.1 \%(4.9 \% ; \mathrm{n}=6)$ of body length, $66.4-71.3 \%$ $(69.4 \% ; n=7)$ of maximum body width, substantially larger than ventral sucker (Figs 1, 5, 7). Prepharynx short. Pharynx subspherical, muscular, surrounded by numerous gland cells densely grouped (Fig. 1), 280-465 (333; n = 7) long, 320-449 (381; n = 7) wide. Esophagus short. Intestinal bifurcation in midforebody, 1.07-1.32 (1.12; $\mathrm{n}=7) \mathrm{mm}$ from anterior end. Intestinal ceca slightly sinuous anteriorly or not, of unequal length, terminate at posterior region of body (Fig. 1). Ventral sucker ovate, 600-723 $(655 ; \mathrm{n}=7)$ long, 590-770 $(662 ; \mathrm{n}=7)$ wide, in anterior third of body, $4.8-5.7 \%(4.9 \% ; n=7)$ of body length, $52.1-60.1 \%(55.4 \%$; $\mathrm{n}=7$ ) of maximum body width. Oral sucker width to ventral sucker width ratio 1.19-1.32 (1.26):1. Testes entire, distinctly ovate, tandem, sometimes oblique, in middle third of body (Fig. $1)$; anterior testis 600-900 (746; $\mathrm{n}=6)$ long, 380-510 (436; $\mathrm{n}$ = 6) wide, posterior testis 660-854 (743; $\mathrm{n}=5$ ) long, 420-501 $(474 ; \mathrm{n}=5)$ wide; distance between testes $1.32-1.88(1.56 ; \mathrm{n}=6)$ mm long, occupying $9.3-13.7 \%(11.9 \% ; n=6)$ of body length; post-testicular region 3.22-5.96 (5.11; $\mathrm{n}=6) \mathrm{mm}$ long, occupying $27.6-44.2 \%(38.5 \% ; n=6)$ of body length. Cirrus sac oblong (Fig. 2), 1.630-2.041 (1.809; $\mathrm{n}=7$ ) $\mathrm{mm}$ long, 240-333 (270; $\mathrm{n}=7$ ) wide, situated longitudinally between anterior margin of ventral sucker and at 190-460 (304; $\mathrm{n}=5)$ from anterior margin of ovary; contains tubular, coiled seminal vesicle and unarmed cirrus; cirrus muscular with papillated internal surface (Figs 8-9). Prostatic cells fill available space outside seminal vesicle and ejaculatory duct (Fig. 2). Genital pore immediately anterosinistral to ventral sucker (Figs 1, 2, 5). Ovary rounded, entire, submedian, 430-500 (456; $\mathrm{n}=7$ ) long, 370-457 (400; $\mathrm{n}=7$ ) wide; distance between ovary and anterior testis $1.03-1.81(1.33 ; \mathrm{n}=7) \mathrm{mm}$ long, occupying $7.8-12.8 \%(10.1 \% ; n=7)$ of body length. Seminal receptacle almost reniform (Figs 1, 3), post-ovarian, 105-212 (174; $\mathrm{n}=7$ ) long, 99-215 (140; $\mathrm{n}=7)$ wide. Laurer's canal not observed. Vitellaria in form of numerous bunch-like clusters of small follicles, intercecal, cecal and extracecal, extending from post-ovarian zone to near end of ceca (Fig. 1). Uterus intra- and extracecal, passes between testes and occupies most of post-ovarian part of hindbody (Fig. 1). Egg small, ovoid, operculated, thin shelled (Fig. 4), 24-30 (26; $\mathrm{n}=7)$ long, $13-17(15 ; \mathrm{n}=7)$ wide. Excretory vesicle not observed. Excretory pore terminal, at middle line of posterior end of body (Fig. 12). 


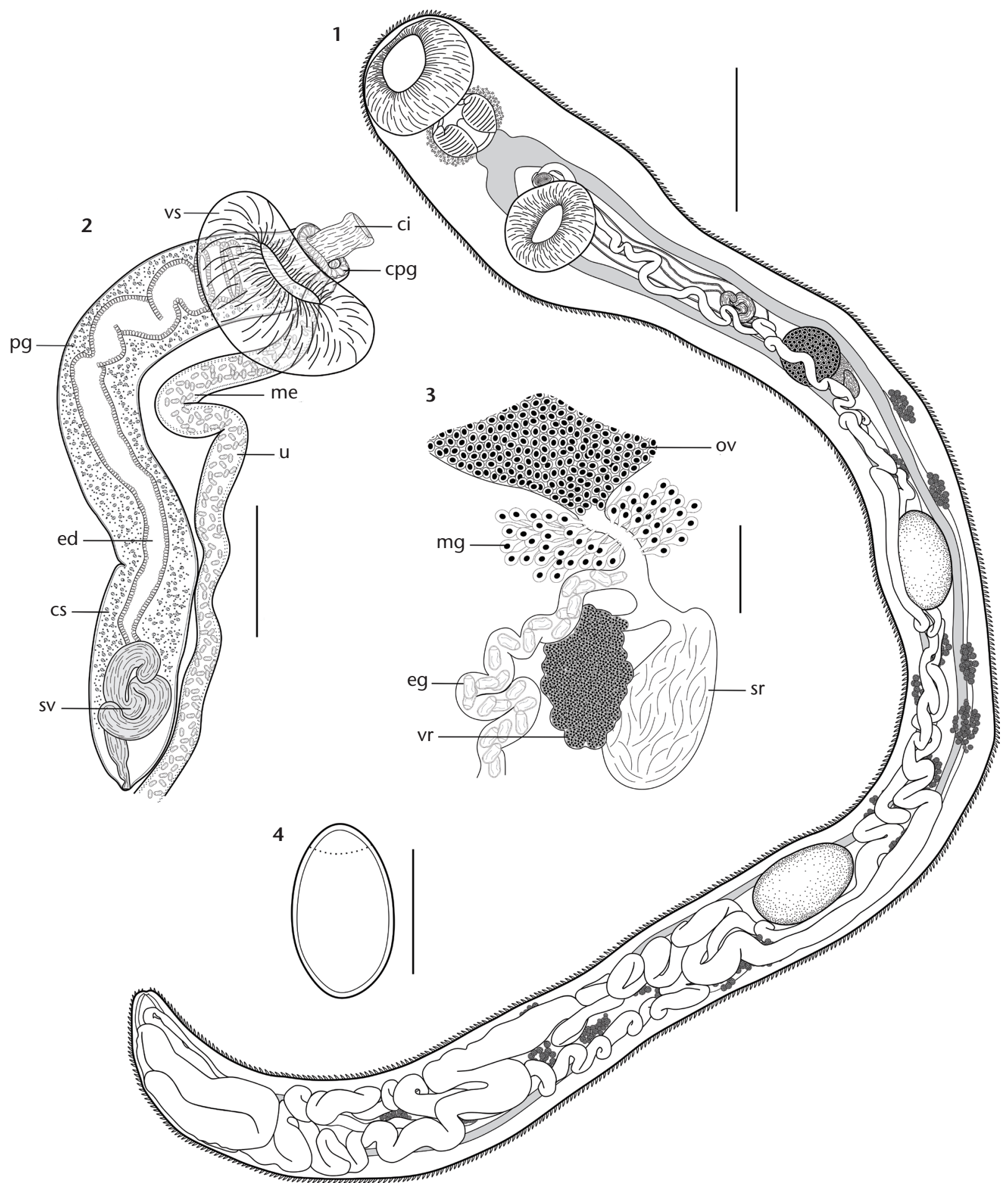

Figures 1-4. Glossidiella peruensis sp. nov. from lungs of brown ground snake Atractus major, holotype : (1) body, ventral view; (2) terminal genitalia, (3) ovarian complex ; (4) egg. (ci) Cirrus, (cgp) common genital pore, (cs) cirrus sac, (ed) ejaculatory duct, (eg) egg, (me) metraterm, (mg) Mehlis' gland, (ov) ovary, (pg) prostatic glands, (sr) seminal receptacle, (sv) seminal vesicle, (u) uterus, (vr) vitelline reservoir, (vs) ventral sucker. Scale bars: 1, $2=500 \mu \mathrm{m}, 3=100 \mu \mathrm{m}, 4=20 \mu \mathrm{m}$. 


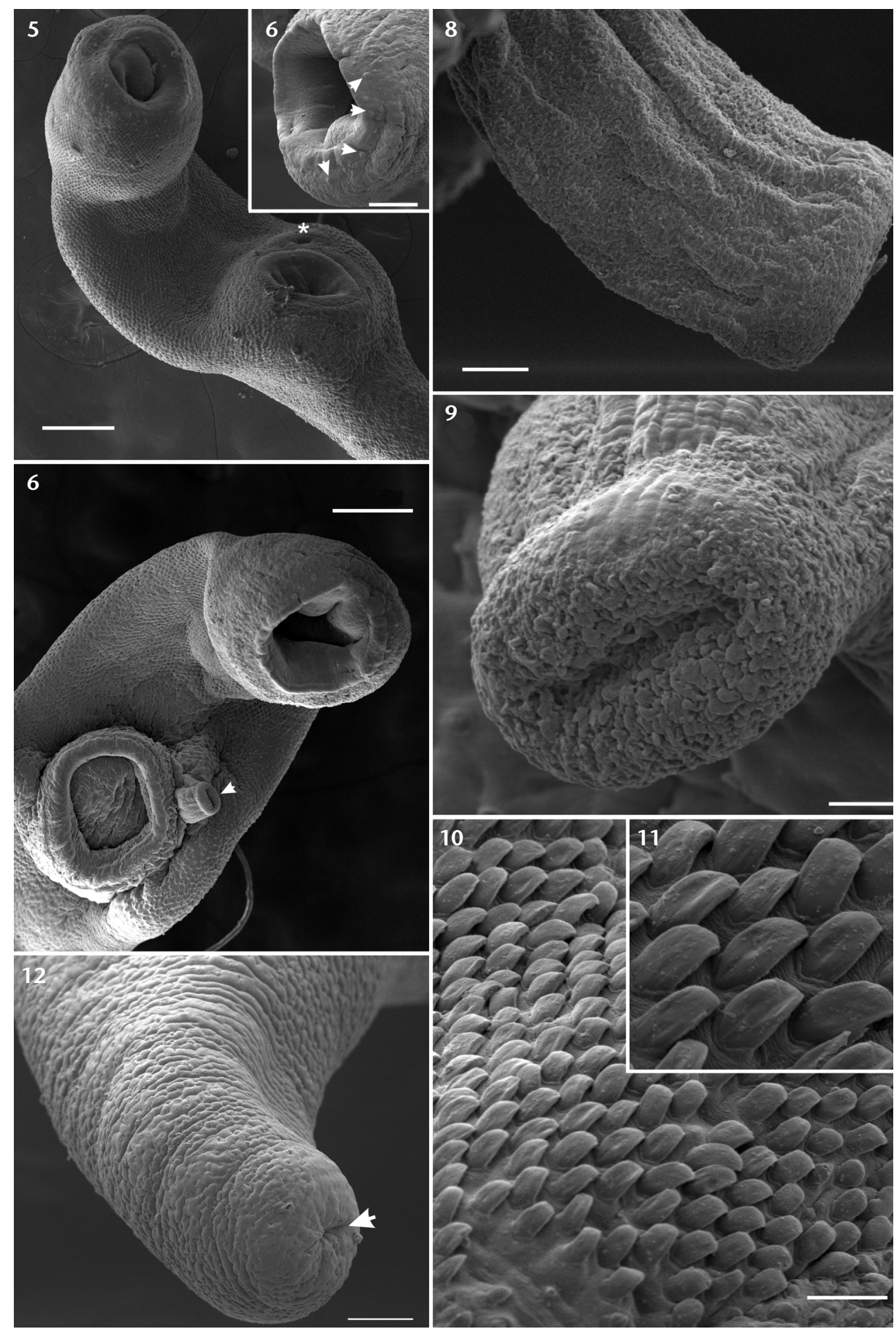

Figures 5-12. Glossidiella peruensis sp. nov. from lungs of brown ground snake Atractus major. Scanning electron micrographs: (5) forebody, lateral view; (6) oral sucker region with small button-like papillae distributed on dorsal surface, indicated by arrows; (7) Forebody, ventral view, showing cirrus, indicated by an arrow; (8) cirrus, lateral view; (9) cirrus, apical view; (10-11) spines; (12) posterior end of body with excretory pore, indicated by an arrow. Scale bars: $5,7=200 \mu \mathrm{m}, 6=10 \mu \mathrm{m}, 8=25 \mu \mathrm{m}, 9=15 \mu \mathrm{m}, 10=25 \mu \mathrm{m}, 11=10 \mu \mathrm{m}, 12=50 \mu \mathrm{m}$. 
Etymology. The specific epithet refers to the country where the species was found.

Remarks. Based on the presence of an unarmed genital pore at the level of the ventral sucker and the absence of an external seminal vesicle, the new species belong to the Plagiorchiidae Lühe, 1901 (Tkach 2008). It is assigned to Glossidiella as it exhibits the following combination of morphological features: tegument with spines; ventral sucker in anterior third of the body; a long cirrus sac, containing a coiled seminal vesicle; a genital pore immediately anterosinistral to the ventral sucker; vitelline follicles forming numerous bunch-like clusters on either side of the body extending from the ovary to near the cecal extremities; and an intra and extracecal uterus that passes between the testes and occupies most of post-ovarian part of hindbody (Tkach 2008). Glossidiella is a monotypic genus and was originally proposed for a digenean species, G. ornata Travassos, 1927 found in the lung of the false water cobra, $H y$ drodynastes gigas (Duméril, Bibron \& Duméril, 1854) (= Cyclagras gigas) (Dipsadidae) in Brazil (Travassos 1927, 1928, Tkach 2008, Fernandes and Kohn 2014). Glossidiella peruensis sp. nov. is readily separated from $G$. ornata by its oblong cirrus sac, rather than being claviform as in $G$. ornata and by having button-like papillae on the dorsal edge of the oral sucker that are absent in G. ornata (present study; based on type materials). Furthermore, the testis of $G$. peruensis sp. nov. are distinctly ovate and well separated from each other, whereas they are rounded and near to each other in G. ornata. Finally, Glossidiella peruensis sp. nov. possesses substantially wider oral $(66.4-71.3 \%$ vs $36.2-42.1 \%$ of maximum body width) and ventral suckers (52.1-60.1\% vs $30-38.2 \%$ of maximum body width).

\section{DISCUSSION}

Peru is known as one of the ten most biodiverse countries on earth (Schlüter et al. 2004). Regarding to its reptile fauna, it is one the five most diverse countries worldwide, harboring 499 species of native reptiles belonging to the following three orders: Squamata (447 spp.), including Sauria (232 spp.), Serpentes (234 spp.) and Amphisbaenia (7 spp.), Testudines (19 spp.) and Crocodylia (5 spp.) (Uetz et al. 2016). Despite this great diversity, information on its parasite diversity is very scarce considering its importance as biological indicators of disturbed habitat. To date the helminth parasites of reptiles, specially digeneans, have been poorly explored (McAllister et al. 2010). Actually, nine species of digeneans in reptiles have been reported from Peru, namely Helicotrema spirale (Diesing, 1850) Odhner, 1912 (Liolopidae); Podocnemitrema papillosus Alho \& Vicente, 1964 (Microscaphidiidae); Halltrema avitellina Lent \& Freitas, 1939; Halltrema heteroxenum (Cordero \& Vogelsang, 1940) Jones, 2005; Nematophila grandis (Diesing, 1839) Travassos, 1934 (Cladorchiidae); Orchidasma amphiorchis (Braun, 1899) Looss, 1900; Telorchis hagmanni Lent \& Freitas, 1937 (Telorchiidae); Adenogaster serialis Looss, 1899; and Cricocephalus albus (Kühl \& van Hasselt, 1822) Looss, 1899
(Pronocephalidae), all of which were recovered from aquatic or terrestrial turtles (Tantaleán et al. 1992, Tantaleán and Forlong 2013, Fernandes and Kohn 2014, Werneck and Da Silva 2016, Gomez-Puerta et al. 2017). Therefore, additional parasitological surveys are needed to comprehend the true digenean richness in reptiles of Peru; this study expands this knowledge adding a new species of Glossidiella infecting the lung of the brown ground snake. Glossidiella ornata is the only known species described in the genus and was described from $H$. gigas collected from Brazil. Subsequently, G. ornata has been reported parasitizing $H$. gigas (= C. gigas) in Argentina (Poumarau 1968, Martínez et al. 1996, Sutton and Damborenea 2000, Lunaschi and Drago 2007). Glossidiella peruensis sp. nov. is the second species in Glossidiella and the first digenean species described from a snake in Peru.

The Plagiorchiidae Lühe, 1901 is a large family of digeneans distributed globally in tetrapod hosts (amphibians, reptiles, birds and mammals) (Tkach 2008). In South America, 17 species belonging to 11 genera of Plagiorchiids have been described from several reptile species. Only seven digenean species have been reported from snakes of the Dipsadidae (Fernandes and Kohn 2014). Glossidiella peruensis sp. nov. is the eighth species of plagiorchiids from dipsadid snakes in South America.

\section{ACKNOWLEDGMENTS}

Thanks are due to Marcelo Knoff curator of the Coleção Helmintológica do Instituto Oswaldo Cruz (CHIOC) and Daniela A. Lopes for the loan of the specimens analyzed in the present study. We also thank Alex Vela Noriega and Blanca Saldaña Arévalo for assistance in the parasitological examinations. The authors are thankful to the Staff of the Laboratory of Specialized Equipment from the National University of San Marcos (UNMSM) for the support in SEM observations. José L. Luque was supported by a Researcher fellowship from the Conselho Nacional de Desenvolvimento Científico e Tecnológico (CNPq), Brazil. Jhon D. Chero and Celso L. Cruces were supported by a student fellowship from the Coordenação de Aperfeiçoamento de Pessoal do Ensino Superior, Brazil (CAPES) - Finance Code 001.

\section{LITERATURE CITED}

Arteaga A, Mebert K, Valencia JH, Cisneros-Heredia DF, Peñafiel $\mathrm{N}$, Reyes-Puig C, Vieira-Fernandes JL, Guayasamin JM (2017) Molecular phylogeny of Atractus (Serpentes, Dipsadidae), with emphasis on Ecuadorian species and the description of three new taxa. ZooKeys 661: 91-123. https://doi. org/10.3897/zookeys.661.11224

Fernandes BMM, Kohn A (2014) South American trematodes parasites of amphibians and reptiles. Rio de Janeiro, Oficina de Livros, 228 pp.

Gomez-Puerta L, Bachmann V, Quiñones J, Quispe S, Torres D, Macalupu J (2017) Primer reporte de Cricocephalus albus (Digenea: Pronocephalidae) en el Perú, parásito de la tortu- 
ga verde del Pacífico Este (Chelonia Mydas agassizii). Revista Peruana de Biología 24: 217-22. https://doi.org/10.15381/ rpb.v24i2.13501

Kuzmin Y, de Vasconcelos Melo FT, dos Santos JN (2014) A new species of Serpentirhabdias Tkach, Kuzmin \& Snyder, 2014 (Nematoda: Rhabdiasidae) parasitic in the brown ground snake Atractus major Boulenger (Reptilia: Serpentes: Dipsadidae) in Brazil. Systematic Parasitology 89: 101-106. https:// doi.org/10.1007/s11230-014-9520-5

Lunaschi LI, Drago FB (2007) Checklist of digenean parasites of amphibians and reptiles from Argentina. Zootaxa 1476: 51-68.

Martínez FA, Troiano JC, Binda JL, Selles DE, Jara D, Fescina N (1996) Trematodes of some ophidians of the north east of Argentina. Cuaderno de Herpetologia 9: 85-94.

Martins M, Oliveira ME (1999) Natural history of snakes in forests of the Manaus region, Central Amazonia, Brazil. Herpetological Natural History 6: 78-150.

Mcallister CT, Bursey CR, Freed PS (2010) Helminth parasites of amphibians and reptiles from the Ucayali region, Peru. Journal of Parasitology 96: 444-447. https://doi.org/10.1645/ GE-2206.1

Myers CW (2003) Rare snakes - five new species from eastern Panama: reviews of northern Atractus and southern Geophis (Colubridae: Dipsadinae). American Museum Novitates 3391: 1-47.

Nogueira C, Cisneros-Heredia DF, Catenazzi A, Gonzales L, Schargel W, Rivas G (2016) Atractus major. The IUCN Red List of Threatened Species 2016: e.T176355A44877793. https://doi.org/10.2305/IUCN.UK.2016-1.RLTS. T176355A44877793.en

Passos P, Fernandes R (2008) A new species of the colubrid snake genus Atractus (Reptilia: Serpentes) from the central Amazon of Brazil. Zootaxa 1849: 59-66.

Poumarau EMC (1968) Trematodes de ofidios de la Argentina. Revista del Museo Argentino de Ciencias Naturales "Bernardino Rivadavia" e Instituto Nacional de Investigación de las Ciencias Naturales Parasitologia1: 1-129.

Schlüter A, Icochea J, Perez JM (2004) Amphibians and reptiles of the lower Río Llullapichis, Amazonian Peru: Updated species list with ecological and biogeographical notes. Salamandra 40: 141-160.

Sutton CA, Damborenea MC (2000) Colección helmintológica del Museo de La Plata: I Catálogo de preparaciones microscópicas, materiales tipo y no tipo. Revista del Museo de La Plata 35: 1-20.

Uetz P, Freed P, Hošek J [Eds] (2016) The Reptile Database. World Wide Web electronic publication. http://www.reptile-database.org [version 12/2016]

Tantaleán MV, Sarmiento LB, Huiza AF (1992) Digeneos (Trematoda) del Perú. Boletín de Lima 80: 47-84.

Tantaleán M, Forlong J (2013) New flukes in turtle and tortoise Chelonoidis denticulate and Podocnemis unifilis in Iquitos, Peru. Peruvian Journal of Parasitology 21: 32-35.

Tkach VV (2008) Family Plagiorchiidae Lühe, 1901. In: Bray RA, Gibson DI, Jones A (Eds) Keys to the Trematoda. CABI, Wallingford, 295-325.

Travassos L (1927) Trematódeos novos. V. Boletim Biológico 7: 95-101.

Travassos L (1928) Fauna helminthologica de Mato Grosso. Memorias do Instituto Oswaldo Cruz 21: 309-372.

Werneck M, Da Silva RJ (2016) Checklist of sea turtles endohelminth in Neotropical region. Helminthologia 53: 211-223. https://doi.org/10.1515/helmin-2016-0045

Submitted: August 6, 2019

Accepted: September 25, 2019

Available online: February 25, 2020

Editorial responsibility: Walter A. Boeger

Author Contributions: EH, GS, CLC, CM, JLL and JDC contributed equally to this article.

Competing Interests: The authors have declared that no competing interests exist.

(C) 2020 Sociedade Brasileira de Zoologia. Published by Pensoft Publishers at https://zoologia.pensoft.net 